\title{
Spray Container
}

National Cancer Institute

\section{Source}

National Cancer Institute. Spray Container. NCI Thesaurus. Code C149948.

Container for a liquid pharmaceutical form to be converted into a spray by mechanical means. 